Management and Economics Journal

E-ISSN : 2598-9537 P-ISSN : 2599-3402

Journal Home Page: http://ejournal.uin-malang.ac.id/index.php/mec

Volume 4 Number 3, December 2020

\title{
Analysis The Effect of Trading Volume Activity and External Factors to Composite Stock Price Index
}

Mega Barokatul Fajri ${ }^{\star}$

Faculty of Economics and Business, University of

Muhammadiyah Lamongan, Indonesia

megabarokatulf1@gmail.com

\section{Wihandaru}

Faculty of Economics and

Business, University of

Muhammadiyah Yogyakarta, Indonesia

\section{Adi Lukman Hakim}

Faculty of Economics and

Business, University of

Muhammadiyah Lamongan, Indonesia

\begin{abstract}
This research as a purpose to analyze the effect of trading volume activity and external factors such as exchange rates, BI Rate to composite stock price index listed on the Indonesian Stock Exchange. The object of this research is on the Indonesia Stock Exchange and Bank Indonesia. In this study, the data used were time-series data and the sampling method used was purposive sampling. The method of analysis used in this study is multiple regression models. Based on the analysis that has been done, it is known that the trading volume activity and BI Rate has no effect on the composite stock price index, while the exchange rate has a negative effect on the composite stock price index.
\end{abstract}

Keywords: Trading Volume Activity, Exchange Rate, BI Rate, IHSG

\section{INTRODUCTION}

In this era, the development of the capital market in Indonesia is very large, many of the people are starting to wake up to invest in the capital market. The development of the capital market can be seen from the changes in the price of shares being traded and the trading volume of the shares themselves. The capital market is one of the sources of private-sector funds that the government hopes to increase investment and economic growth. As an economic instrument, the capital market cannot be separated from environmental influences, both internal and external. The influence of the internal economic environment, such as company performance, changes in corporate strategy, dividends, and the external economic environment, such as interest rates on savings and deposits, foreign exchange rates, inflation, and various regulations and economic deregulation issued by the government. These two aspects greatly influence stock price fluctuations and share trading volume. External factors that are proven to influence stock price movements in Indonesia are the exchange rate and the $\mathrm{BI}$ Rate, and the internal factor that can affect share prices is the volume of stock trading. The size of the demand for shares in the market can affect the volume of stock trading, and this has an impact on changes in stock prices in the market. 
This research is based on a phenomenon that occurred in Indonesia in 2015, this year the state of the Indonesian economy is experiencing a depreciation, this has greatly affected all economic activities in Indonesia, which is a developing country where the economy is not stable. On the other hand, there are fluctuations in share trading volume caused by fluctuations in exchange rates. The existence of fluctuations in the volume of stock trading greatly affects changes in stock prices, especially in the composite stock price index (IHSG). On the other hand, besides the phenomenon that occurs in Indonesia, there is a research gap that makes researchers want to observe in more detail the influence of trading volume activity and external factors that affect the composite stock price index. Several previous studies have been conducted by Mutakif and Nurwulandari (2014) which states that trading volume activity has a positive effect on the composite stock price index. According to Divianto (2013) and Putri, Darmawan, \& Sulistyanto (2015) state that the $\mathrm{BI}$ rate has a negative effect on the composite stock price index, while according to Mardiyati and Rosalina (2013) states that the BI Rate has a positive and insignificant effect on the composite stock price index. And according to Kewal (2012) states that the BI Rate has no effect on the composite stock price index. According to Divianto (2013), Mardiyati et al., (2013) and Kewal (2012) state that exchange rate has a negative and significant effect on the composite stock price index, while according to Putri et al., (2015) states that exchange rates have a significant positive effect on the composite stock price index. Based on this phenomenon and research gap, the researcher is interested in analyzing the effect of trading volume activity and external factors such as the exchange rate and the BI Rate on the composite stock price index (IHSG).

\section{THEORETICAL REVIEW}

\section{Trading Volume Activity}

Trading volume activity is the number of shares traded on the capital market. Trading volume activity is important for investors because the trading volume activity describes the conditions of securities traded in the capital market which can have an impact on stock prices (Ferdhani, 2014). According to Husnan (2015), trading volume is a function of supply and demand and can be used as a sign of changes in market strength and weakness. Trading volume in the capital market can be an important indicator for investors. An increase in trading volume activity is an increase in buying and selling activity by investors in the capital market.

\section{The Exchange Rate}

According to Nopirin (2011), the exchange rate is the price in exchange for two different kinds of money. According to Dornbusch., Fischer, , \& Starz (2008), the exchange rate system is divided into fixed exchange rates and floating exchange rates. The fixed exchange rate system is a condition in which the domestic currency exchange rate is determined by the government. So that the government has the right to intervene through various policies in regulating every movement of the exchange rate. And the floating exchange rate system is a system in which the government and the market both 
have the freedom to determine currency exchange rates. So that the government does not have the right to intervene in regulating exchange rate movements.

BI Rate

According to Bank Indonesia, the BI Rate is a policy that reflects the monetary policy stance or stance set by Bank Indonesia and announced to the public. The Bi Rate is announced by the Board of Governors of Bank Indonesia at every monthly Board of Governors Meeting and implemented in monetary operations conducted by Bank Indonesia through liquidity management in the money market to achieve the operational targets of monetary policy (Indonesia, 2015). According to Siamat (2010), the $\mathrm{BI}$ Rate is an interest rate with a tenor of one month which is announced by Bank Indonesia periodically for a certain period which functions as a monetary policy signal.

\section{Composite Stock Price Index}

The composite stock price index is a composite index of all types of shares listed on the stock exchange. The composite stock price index is published by the stock exchange. Stock price fluctuations in the market occur due to supply and demand factors. Various variables affect the demand and supply such as interest rates, inflation rates, foreign exchange rates, and some of the behavior of investors that quickly change whenever they hear about issues. In general, the increase and decrease in prices can occur together, therefore if the increase or decrease in prices continues, it will be followed by a reversal. This proves that in an increase or decrease there is always an error called overreaction or mispriced. If the price continues to rise, it will be followed by a decline in prices in the next period (Samsul, 2006).

\section{Development of Hypothesis}

\section{The Effect of Trading Volume Activity to Composite Stock Price Index}

Trading volume activity is a function of supply and demand and can be used as a sign of changes in market strengths and weaknesses. Trading volume activity in the capital market can be an important indicator for investors. The increase in trading volume activity is an increase in buying and selling activities by investors in the capital market (Husnan, 2015). When the increase in share buying activity in the capital market increases, the share price will increase. The greater the number of shares traded on the capital market, the higher the share trading volume. And if you are more actively trading shares in the capital market, it can increase the stock price. This is following the demand theory, the more demand for goods will cause the price of goods to increase. Following the empirical study conducted by Mutakif et al., (2014) examining the effect of trading volume, exchange rate, and the Hang Seng index on the composite stock price index, the results of this study indicate that there is a positive and significant effect on the composite stock price index. However, according to the results of research conducted by Peter (2011) it shows that trading volume activity does not have a significant effect on stock prices. Because at that time investors paid less attention to the amount of trading volume that occurred because investors in choosing stocks tended to be based on 
market reactions and desires. Based on the framework above, it can be concluded that trading volume has a positive effect on the composite stock price index.

$\mathrm{H}_{1}$ : Trading volume activity has a positive and significant effect on the composite stock price index.

\section{The Effect of Exchange Rate to Composite Stock Price Index}

Foreign exchange rates are the prices of foreign currencies in units of the domestic currency. The exchange rate is one of the factors that can affect a country's economy. The good and bad of a country's economy can be seen from the pros and cons of the currency's value. the exchange rate has a role as a tool to balance the supply and demand for existing assets. Every investor in investing will consider the risks they will face. One of the risks that investors will face in investing is the change in the exchange rate of the rupiah against the dollar. When the rupiah depreciates, this will result in a decrease in the interest of an investor to buy shares, when investor interest decreases it will affect the stock price. Because when the rupiah depreciates against the dollar, it can affect the decline in a company's financial performance, which is reflected in declining corporate profits. When profits decline, investors will consider investing in the company again so that it can affect the decline in share prices due to investors' lack of interest in investing their funds in the company. This is consistent with what was written by Samsul (2006) that a sharp increase in exchange rates will have a negative impact on importoriented issuers. When the rupiah appreciates against the dollar, this will result in investors wanting to sell shares because at that time an investor will think that speculation in the foreign exchange market is better than investing in the stock market, this will result in a decline in stock prices. Following an empirical study conducted by Mutakif et al., (2014), the exchange rate has a negative effect on stock prices. This is reinforced by research conducted by Lailia., Darminto \& Hidayat (2014) Wijaya (2013), Ismawati, Linna \& Hermawan (2013), and Kewal (2012) that the value of exchange rates has a negative effect on stock prices. However, in an empirical study conducted by Putri et al., (2015), it shows that the exchange rate has a positive effect on stock prices. Because when the interest rate decreases and the rupiah exchange rate strengthens, it causes the composite stock price index to increase. Based on the framework above, it can be concluded that the value of the rupiah exchange rate against the dollar has a negative effect on the composite stock price index.

H2: The exchange rate against the dollar has a negative effect on the composite stock price index.

\section{The Effect of BI Rate to Composite Stock Price Index}

The interest rate used in this research is the benchmark interest rate or the $\mathrm{BI}$ Rate. $\mathrm{BI}$ Rate is a policy interest rate that reflects the attitude or monetary policy stance set by

Bank Indonesia and announced to the public (Indonesia, 2015). According to Lailia et al., (2014), changes in the BI Rate set by the government through Indonesian banks will inevitably be followed by changes in deposit interest rates and eventually will be followed by bank lending rates. The BI Rate is an interest rate with a tenor of one month 
announced by Bank Indonesia periodically for a certain period which serves as a signal for monetary policy (Siamat, 2010). Interest rates can be one of the guidelines for investors in making investment decisions in the capital market. An increase in interest rates will result in a decrease in stock prices because when interest rates increase, stock investors will be more interested in saving their funds in the form of deposits than investing their capital in stocks so that it will result in many investors selling the shares they own. This will have a negative effect on the stock price. According to Gujarati \& Dawn (2011), the share price and interest rates have an inverse relationship. That is, if the interest rate is high, the stock price is low, on the other hand, if the interest rate is low, the stock price will be high. According to Tandelilin (2010), a high-interest rate is a negative signal for stock prices. because an increased interest rate can increase the implied interest rate on investment. On the other hand, an increase in interest rates makes investors withdraw their investment in stocks and shift to other investments such as savings and time deposits. Based on the theory above, that when interest rates increase, stock prices will decrease and vice versa. So, it can be concluded that interest rates have a negative effect on stock prices. Following the empirical study conducted by Lailia et al., (2014) that the BI Rate has a negative effect on stock prices. This is reinforced by research conducted by Suryanto (2012) and Divianto (2013), which concluded that the BI Rate has a negative effect on stock prices. Based on the above framework, it can be concluded that the BI Rate has a negative effect on the composite stock price index.

H3: BI Rate has a negative effect on the composite stock price index.

\section{METHODOLOGY}

The object of this research was conducted at the Indonesia Stock Exchange and Bank Indonesia during the period 1 September 2014-30 September 2015. The type of data used in this study is time-series data. In this study using a purposive sampling method in sampling, with the following criteria: on the variable volume of stock trading and the combined stock price the data used is daily data starting from September 1, 2014-30, September 2015, and the data is published on the Indonesia Stock Exchange. ; For the exchange rate variable, the data used are data on the middle exchange rate of the rupiah against the dollar for one period and the data is published by Bank Indonesia; In the BI Rate variable, the data used are monthly data from the BI Rate for one period; and the last criterion is that all samples used are listed on the Indonesia Stock Exchange and Bank Indonesia during one period.

In this study, the dependent variable used is the composite stock price index, the proxy used in this variable is to calculate the stock price at closing for a period. The independent variables used in this study are the trading volume activity, the exchange rate against the dollar, and the $\mathrm{BI}$ Rate. The first independent variable is trading volume activity, to measure this variable the proxy used is to divide the number of shares traded by the number of shares outstanding. 


\section{TVA = (Number of Shares Traded/Number of Shares Outstandine)}

The second independent variable is the exchange rate, the proxy used in measuring this variable is to use the middle exchange rate while the formula used is as follows:

\section{Middle Rate $=($ Selling Rate + Buying Rate $) / 2$}

The last independent variable is the BI Rate. To measure this variable, the proxy used is to look at the BI Rate per month that has been determined and issued by Bank Indonesia. To test and analyze each hypothesis, this study uses a multiple regression model that is tested using SPSS. The following is the form of the equation model used in this study.

$$
Y=b o+b_{1} X_{1}+b_{2} X_{2}+b_{3} X_{3}+\text { e atau IHSG }=\text { bo }+b_{1} \text { TVA }_{t}+b_{2} \text { Kurs }_{t}+b_{3} \text { Rate }_{t}+e_{t}
$$

In the regression model, it can be said that it meets the requirements as an empirical model if the model used can successfully pass a series of classical assumption tests. Therefore, this study uses a classic assumption test so that the model used in this study is feasible to use. The classical assumption test used is the multicollinearity test, autocorrelation test, heteroscedasticity test, and normality test.

\section{RESEARCH RESULTS}

Statistical Descriptive Test

Table 1. Descriptive Analysis

\begin{tabular}{llllll}
\hline & N & Minimum & Maximum & Mean & Std Deviation \\
\hline IHSG & 269 & $-20,4657616$ & 341,2195779 & 173,796289501 & 47,4782626454 \\
TVA & 269 & $-0,001586395$ & 0,001514027 & 0,00004507098 & 0,000317602257 \\
Kurs & 269 & 0,161781691 & 0,161957969 & 0,16185603435 & 0,000042995369 \\
BI Rate & 269 & 0,0002125 & 0,0051250 & 0,002645167 & 0,0002153423 \\
Valid N (listwise) & 269 & & & & \\
\hline
\end{tabular}

Table 1 shows that the amount of data used in this study was 269 data samples. The average value of the daily combined share price is $173,796289501 \%$. The highest value of the combined share price was $341,2195779 \%$ while the lowest value of the combined stock price was $-20.4657616 \%$. The standard deviation that exceeds the average value of the stock price with a coefficient of variation of $0.2731 \%$ indicates a high fluctuation of data on the variable stock price during the observation period.

The lowest trading volume activity value is $-0,001586395$ and the highest is 0,001514027 . Besides, the volume of stock trading shows an average value of 0,00004507098 with a standard deviation of 0,000317602257 . By looking at the value of the standard deviation that is greater than the average, it shows that the data used in this variable has a large data distribution with a coefficient of variation of $7,406 \%$. Thus, it can be concluded that the data on the trading volume variable is not good. 
The lowest exchange rate was 0,161781691 and the highest was 0,161957969. On the other hand, the exchange rate shows an average value of 0,16185603435 with a standard deviation value of 0,000042995369. By looking at the value of the standard deviation that is smaller than the average, this shows that the data used in this variable has a small data distribution with a coefficient of variation of $0,00002656 \%$.

The lowest BI Rate value is 0,0002125 and the highest is 0,0051250 . The average value of this variable is 0,002645167 with a standard deviation value of 0,0002153423 . By looking at the value of the standard deviation that is smaller than the average, this shows that the data used in this variable has a small data distribution with a coefficient of variation of 0,08140 .

\section{Normality Test}

The normality test aims to test whether, in the regression model, the residual variables have a normal distribution. Analysis of data normality testing can be done using the Kolmogorov-Smirnov test. The results of the normality test are shown in the Table 2.

Table 2. Normality Test (Kolmogorov Smirnov)

\begin{tabular}{lll}
\hline & One - Sample Kolmogorov-Smirnov Test \\
& & Unstandardized Residual \\
\hline $\mathrm{N}$ & Mean & 269 \\
Normal Parameters & $0 \mathrm{E}-7$ \\
& Std. Deviation & 45,85054453 \\
Kolmogorov-Smirnov Z & & 1,273 \\
Asymp Sig & & 0,078 \\
\hline
\end{tabular}

Based on the Table 2, it can be seen that the data is normally distributed. This is indicated by the Kolmogorov-Smirnov value having a significant value of 0,078 which is greater than the significance level of 0,05.

\section{Multicollinearity Test}

Multicollinearity test aims to test whether the regression model found a correlation between independent variables (Independent). To find out whether there is multicollinearity, it can be seen from the VIF value shown in the Table 3 .

Table 3. Multicollinearity Test

\begin{tabular}{clcc}
\hline & & \multicolumn{2}{c}{ Collinearity Statistics } \\
& & Tolerance & VIF \\
\hline $\mathbf{1}$ & Constant & & \\
& TVA & 0,998 & 1,002 \\
& Kurs & 0,991 & 1,009 \\
& BI Rate & 0,992 & 1,009 \\
\hline
\end{tabular}


A regression model is declared free of multicollinearity if it has a tolerance value below 1 and a VIF value below 10. From the table above, it is found that all independent variables have a tolerance value below 1 and a VIF value far below the number 10. So, it can be concluded that none multicollinearity symptoms in the regression model are used.

\section{Autocorrelation Test}

The autocorrelation test aims to test whether in the linear regression model there is a correlation between the confounding error in the $t-1$ period (previous). To find out whether autocorrelation occurs, it can be seen from the DW value shown in the Table 4 .

Table 4. Autocorrelation Test

\begin{tabular}{ccccc}
\hline Model & R & R Square & Std.Error Of the Estimate & Durbin-Watson \\
\hline 1 & 0,260 & 0,067 & 46,1093455160 & 1,813 \\
\hline
\end{tabular}

Based on the Table 4, it can be seen that the Durbin Watson value generated in this study is 1,813 . Thus, it can be concluded that this data is located in an autocorrelation free area.

\section{Heteroscedasticity Test}

The heteroscedasticity test aims to test whether in the regression table there is an inequality of variance from the residuals of one observation to another. To find out whether heteroscedasticity occurs, it can be seen from the Table 5 .

Table 5. Heteroscedasticity Test

\begin{tabular}{|c|c|c|c|c|c|}
\hline \multirow[t]{2}{*}{ Model } & \multicolumn{2}{|c|}{ Unstandardized Coefficients } & \multirow{2}{*}{$\begin{array}{c}\text { Standardized } \\
\text { Coefficients } \\
\text { Beta } \\
\end{array}$} & \multirow[t]{2}{*}{$t$} & \multirow[t]{2}{*}{ Sig } \\
\hline & B & Std. Error & & & \\
\hline Constant & $-8358,544$ & 5295,779 & & $-1,578$ & 0,116 \\
\hline TVA & 5361,456 & 4224,751 & 0,080 & 1,269 & 0,206 \\
\hline Kurs & 51844,946 & 32710,801 & 0,100 & 1,585 & 0,114 \\
\hline BI Rate & $-1751,344$ & 6151,091 & $-0,018$ & $-0,285$ & 0,776 \\
\hline
\end{tabular}

Based on the Table 5, it shows that the significant value generated in the heteroscedasticity test exceeds 0,05 . Thus, it can be concluded that this data is free from heteroscedasticity.

\section{Determination Coefficient Test $\left(\mathrm{R}^{2}\right)$}

The coefficient of determination is used to measure the ability of the model to explain the variation in the dependent variable. The results of the calculation of the coefficient of determination are shown in the Table 6 . 
Table 6. Determination Coefficient Test $\left(\mathrm{R}^{2}\right)$

\begin{tabular}{ccccc}
\hline Model & R & R Square & Adjusted R Square & Std.Error Of the Estimate \\
\hline 1 & 0,260 & 0,067 & 0,057 & 46,1093455160 \\
\hline
\end{tabular}

From the calculation results, it is found that the influence of the independent variable on the dependent variable which can be explained by this equation model is 0,057 or $5,7 \%$ and the remaining $94,3 \%$ is influenced by other factors that are not included in the regression model.

\section{Simultaneous Test (F-test)}

The F statistical test is used to show whether all the independent variables included in the model have a joint influence on the dependent variable. The results of the $F$ test calculation can be seen in the following Table 7 .

Table 7. Simultaneous Test (F-test)

\begin{tabular}{cc}
\hline Variable & Coefficient \\
\hline F- Statistic & 6,383 \\
Probabilitas (F-Statistic) & 0,000 \\
\hline
\end{tabular}

From the test results above, it can be seen that together the independent variable has a significant influence on the dependent variable. This can be proven from the calculated $F$ value of 6,383 with a significant value of 0.000 . Because the probability is much smaller than 0,05 , the regression model can be used to predict that the level of trading volume, exchange rate, and the BI Rate simultaneously affect the composite stock price index.

\section{Partial Test (t-test)}

The $t$ statistical test is used to show whether all the independent variables included in the model have a partial effect on the dependent variable. The results of the t-test calculation can be seen in the following Table 8 .

Table 8. Partial Test (t-test)

\begin{tabular}{lllllll}
\hline & Model & \multicolumn{2}{c}{$\begin{array}{c}\text { Unstandardized } \\
\text { Coefficients }\end{array}$} & $\begin{array}{c}\text { Standardized } \\
\text { Coefficients }\end{array}$ & $\begin{array}{c}\text { t- } \\
\text { Statistic }\end{array}$ & Probabilitas \\
& \multicolumn{1}{c}{ B } & Std. Error & Beta & & \\
\hline $1 \quad$ C & 45841,933 & 10654,989 & & 4,302 & 0,000 \\
& TVA & 1222,064 & 8878,784 & 0,008 & 0,138 & 0,891 \\
& Kurs & - & 65810,944 & $-0,256$ & $-4,289$ & 0,000 \\
& Bl Rate & 282245,659 & & & & \\
& 5659,825 & 13135,451 & 0,026 & 0,431 & 0,667 \\
\hline
\end{tabular}

Based on the Table 8, it can be seen that the exchange rate has a significant effect on the composite stock price index. This can be seen from the probability value of 0,000 which is smaller than the significance level of 0,05. Meanwhile, the trading volume activity and the BI Rate do not have a significant effect on the composite stock price index. This can be seen from the magnitude of the probability value that exceeds the 
significance level of 0,05 . As for the probability value of TVA is 0,0891 and the probability value on the BI Rate variable is 0,667 .

\section{DISCUSSION OF HYPOTHESIS TESTING RESULTS}

\section{The Effect of Trading Volume Activity to Composite Stock Price Index}

The first hypothesis states that the level of stock trading volume has a positive effect on the composite stock price index. The regression results show that the resulting probability value is 0,891 , exceeding the $5 \%$ significance level. Thus, the first hypothesis which states that stock trading volume has a positive effect on the composite stock price index cannot be accepted or rejected. The insignificant research results can be proven by the graphic image below.

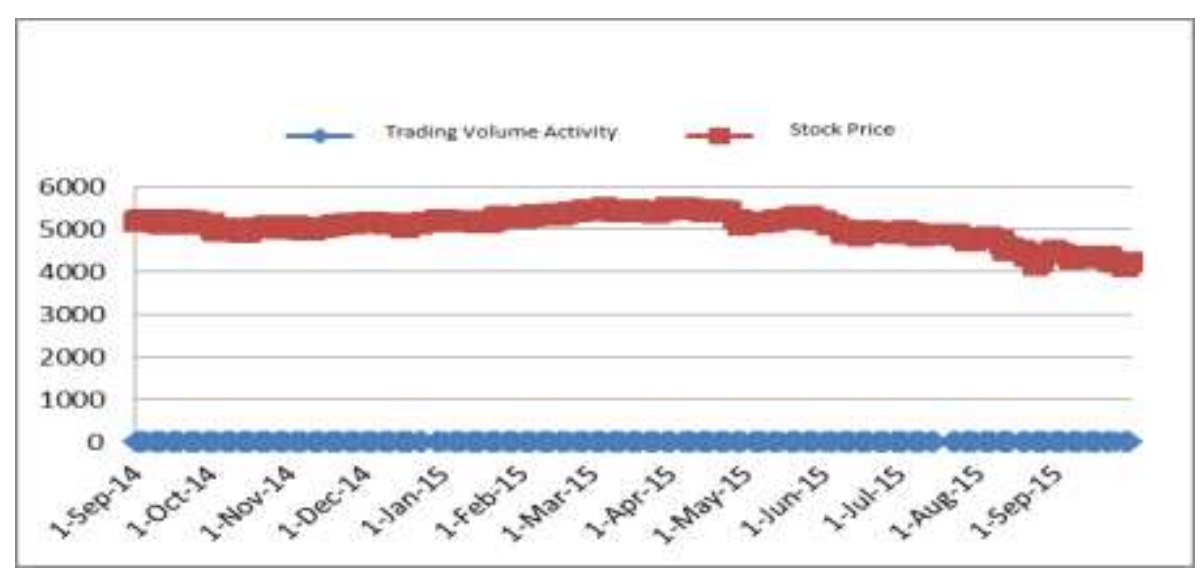

Graph 1. Comparison of Trading Volume Activity \& Composite Stock Price Index

The test results on trading volume activity are not following the framework in the above hypothesis, which states that the more shares traded on the capital market, the higher the trading volume activity. And if you are more actively trading shares in the capital market, it can increase the stock price. This can be seen in the chart above, that the level of trading volume activity from September 2014 to September 2015 was stagnant and did not fluctuate, while the composite stock price index continued to fluctuate. This proves that the size of the share trading volume does not affect the composite stock price index in the capital market, this incident is because the trading volume activity does not reflect the company's stock price. On the other hand, other factors make the hypothesis on this variable unacceptable, namely because in conducting share purchase transactions investors do not pay attention to the size of the share trading volume that occurs at that time, and investors are more likely to see how the market reacts to these stocks and choose of his own accord.

The results of this study are in line with research conducted by Peter et al., (2011) that the volume of stock trading does not have a significant effect on stock prices because investors do not pay attention to trading volume in purchasing shares on the capital market. 


\section{The Effect of Exchange Rate to Composite Stock Price Index}

The second hypothesis states that the exchange rate has a negative effect on the composite stock price index. From the regression results obtained that the probability value generated is equal to 0,000 , this figure is smaller than the significance level of $5 \%$. Thus, the second hypothesis which states that the exchange rate has a negative effect on the composite stock price index can be accepted.

The regression results above are following the hypothetical framework used. When the rupiah depreciates against the dollar, it can affect the decline in the financial performance of a company, which imports the raw materials it produces. When the amount of imported raw materials increases, the production costs incurred by the company will increase, immediately production costs will increase and have an impact on decreasing company profits. When company profits decline, investors will again consider investing in the company so that it can affect the decline in share prices. This is different when the rupiah appreciates against the dollar, if this happens investors will sell the shares they own because speculation in the foreign exchange market is more profitable than investing in stocks. So that makes the stock price decrease.

The above phenomenon is in line with Indonesia's current conditions, where from September 2014 to September 2015 the value of the rupiah depreciated and caused the composite stock price index to decline.

The results of this study are in line with research conducted by Kewal (2012) and Suryanto (2012) that the rupiah exchange rate has a negative effect on the composite stock price index. This is also following the theory put forward by Samsul (2006), that a sharp increase in exchange rates will have a negative impact on import-oriented issuers and also have an impact on the company's financial performance, so that company profits will decline and share prices will also decline.

\section{The Effect of BI Rate to Composite Stock Price Index}

The third hypothesis states that the BI Rate has a negative effect on the composite stock price index. From the regression results above, it shows that the probability value generated is 0,667 , this figure is much greater than the $5 \%$ significance level. Thus, the third hypothesis which states that the BI Rate has a negative effect on the composite stock price index cannot be accepted.

This contradicts several existing theories, where many theories state that interest rates have an inverse effect on the composite stock price index. This is supported by the theory put forward by Tandelilin (2010), that changes in interest rates will affect stock prices inversely, ceteris paribus. This means that if the interest rate increases, the stock price will decrease, and vice versa. This insignificant research result is because at this time the type of Indonesian investor is an investor who likes to make short-term investments such as stocks rather than investing at the BI Rate. Investments in stocks tend to be faster in obtaining large capital gains, this is inversely proportional to investors investing in the $\mathrm{BI}$ Rate, which is a type of long-term investment and the amount of profit earned is not as large as investing in stocks. 
The regression results above are also reinforced by the results of research conducted by Kewal (2012) which states that interest rates do not have a significant effect on stock prices because the market quickly adjusts interest rate information to stock prices. On the other hand, the results of this study are also reinforced by research conducted by Amin \& Herawati (2012), those interest rates have a significant positive effect on the movement of the composite stock price index, this is because in 2008 there was a condition where there was no cateris paribus, which had happened. The financial crisis was quite large in the United States which had an impact on capital market activities in that country, while at that time Indonesia embraced a global economy and also cooperated through export and import activities with the United States. Many American companies operate in Indonesia, as well as domestic investors, of course, many who invest in the USA and vice versa. This results in whatever happens to the economy of the United States and its capital market, it will also have an impact on the economy and capital market in Indonesia.

\section{CONCLUSION}

This study attempts to examine whether the trading volume activity and external factors such as exchange rates and the BI Rate affect the composite stock price index. Based on the test results, the first hypothesis shows that partially the trading volume activity has no effect on the composite stock price index on the Indonesia Stock Exchange. This is indicated by the probability value of 0.138 which is greater than the significance level of 0,05 . This proves that the first hypothesis is rejected. This insignificant research result is since the majority of investors do not pay attention to the size of the stock trading volume in making share purchase transactions and rather see how the market reacts when buying shares and based on their desires.

Based on the regression results above, it shows that partially the exchange rate has a negative effect on the composite stock price index on the Indonesian Stock Exchange. This can be seen from the probability value of 0,000 with a regression coefficient that shows a negative direction and is far below the 0,05 significance level. This proves that the second hypothesis can be accepted. This significant research result is following previous theory and research that the exchange rate and stock prices have an opposite relationship, meaning that the weaker the rupiah exchange rate against the dollar (rupiah depreciates), the lower the stock price and vice versa.

Based on the results of testing the third hypothesis shows that partially the BI Rate has no effect on the composite stock price index on the Indonesia Stock Exchange. This is indicated by the probability value that exceeds the $5 \%$ significance level of 0,667 . This proves that the third hypothesis is rejected. This insignificant research result is because currently, the type of Indonesian investor is an investor who likes to make short-term transactions such as stocks so that investors tend to take profit-taking in the hope of obtaining a high enough capital gain in the capital market compared to investing in the BI Rate. 


\section{Research Implications}

Based on this research, it can be stated that the theoretical and practical implications are: This research shows that basically every investor doesn't have to look at how much stock trading volume is in investing, they just need to see how the market reacts when stock transactions occur in the market. The results of this research can be used by investors as a reference in investing in the capital market. In investing, an investor must consider how external factors such as interest rates and exchange rates can influence stock price movements. Because stock price movements greatly affect the level of sales and investor transactions in the capital market. Limitations in this study are the lack of independent variables studied, namely stock trading volume, exchange rate and the BI Rate. The sample used in this study is only one year vulnerable. Based on the conclusions described by the researcher, the suggestions that can be given for researchers who will conduct research on a similar topic, it is hoped that it can extend the time used in further research, In addition, researchers recommend adding several variables that can affect the composite stock price index seen from external factors such as the amount of money in circulation, GDP growth and so on.

\section{REFERENCES}

Amin, M. Z. \& Herawati, T. . D. (2012). Pengaruh Tingkat Inflasi, Suku Bunga SBI, Nilai Kurs Dollar (USD/IDR), dan Indeks Dow Jones (DJIA) terhadap Pergerakan Indeks Harga Saham Gabungan di Bursa Efek Indonesoa (BEI) Periode 2008-2011. Jurnal Ilmiah Mahasiswa FEB, 1(1).

Divianto. (2013). Analisis Pengaruh Tingkat Inflasi, Tingkat Suku Bunga SBI, dan Nilai Kurs Dollar AS (USD) terhadap Indeks Harga Saham Gabungan (IHSG) di Bursa Efek Indonesia. Jurnal Ekonomi Dan Informasi Akuntansi (Jenius), 3(2).

Dornbusch, R., Fischer, S., \& Starz, R. (2008). Makro Ekonomi (Edisi Kese). Jakarta: PT. Media Global Edukasi.

Ferdhani, A. (2014). Analisis Hubungan Suku Bunga, Kurs, Volume Perdagangan dan Return Saham IHSG Periode 2003-2013. Universitas Diponegoro.

Gujarati., D.N., \& Dawn, C. P. (2011). Dasar-Dasar Ekonometrika (Edisi Keti). Jakarta: Salemba Empat.

Husnan, S. (2015). Dasar-Dasar Teori Portofolio dan Analisis Sekuritas (Edisi Keli). Yogyakarta: UPPN STIM YKPN.

Indonesia, B. (2015). Pengertian BI Rate.

Ismawati, Linna \& Hermawan, B. (2013). Pengaruh Kurs Mata Uang Rupiah Atas Dollar AS, Tingkat Suku Bunga Sertifikat Bank Indonesia dan Tingkat Inflasi terhadap Indeks Harga Saham Gabungan (IHSG) pada Bursa Efek Indonesia (BEI). Jurnal Ekono Insentif Kopwil4, 7(2).

Kewal, S. S. (2012). Pengaruh Inflasi, Suku Bunga, Kurs dan Pertumbuhan PDB terhadap Indeks Harga Saham Gabungan. Jurnal Economia, 8(1).

Lailia, H., Darminto \& Hidayat, R. R. (2014). Pengaruh Tingkat Suku Bunga, Tingkat Inflasi, 
Nilai Kurs Dollar dan Indeks Strait Times terhadap Indeks Harga Saham Gabungan (Studi pada Bursa Efek Indonesia Periode Januari 2010-Juni 2013). Jurnal Administrasi Bisnis, 12(1).

Mardiyati, U. \& Rosalina, A. (2013). Analisis Pengaruh Nilai Tukar, Tingkat Suku Bunga dan Inflasi Terhadap Indeks Harga Saham Studi Kasus pada Perusahaan Properti yang Terdaftar di Bursa Efek Indonesia. Jurnal Riset Manajemen Sains Indonesia, 4(1).

Mutakif, F. \& Nurwulandari, A. (2014). Pengaruh Volume Perdagangan Saham, Nilai Tukar, dan Indeks Hang Seng terhadap Pergerakan Indek Harga Saham Gabungan. Jurnal Ilmiah Akuntansi Dan Bisnis, 7(2).

Nopirin. (2011). Ekonomi Internasional. Yogyakarta: BPFE.

Peter, R. (2011). Pengaruh Volume Perdagangan dan Kinerja Keuangan terhadap Harga Saham Studi Emiten PT. Astra Agro Lestari Tbk di Bursa Efek Indonesia Pada Periode 2004-2007. Akurat Jurnal Ilmiah Akuntansi, 2(5).

Putri, K.T., Darmawan, N. \& Sulindawati, N. L. (2015). Pengaruh Tingkat Suku Bunga SBI, Kurs Mata Uang Rupiah Atas Dollar AS, dan Indeks Dow Jones terhadap Indeks Harga Saham Gabungan (IHSG) pada Bursa Efek Indonesia (BEI) Periode 2010-2014. E-Journal S1 Ak Universitas Pendidikan Ganesha, 3(1).

Samsul, M. (2006). Pasar Modal dan Manajemen Portofolio. Surabaya: Erlangga.

Siamat, D. (2010). Manajemen Lembaga Keuangan (Edisi Keem). Jakarta: Lembaga Penerbit FE Universitas Indonesia.

Suryanto. (2012). Pengaruh Inflasi, Suku Bunga BI Rate dan Nilai Tukar Rupiah terhadap Harga Saham Perusahaan Sektor Properti Dan Real Estate di Bursa Efek Indonesia. Jurnal Administrasi Bisis Universitas Padjajaran.

Tandelilin, E. (2010). Portofolio dan Investasi Teori Dan Aplikasi (Edisi Pert). Yogyakarta: Kanisius.

Wijaya, R. (2013). Pengaruh Fundamental Ekonomi Makro terhadap Indeks Harga Saham Gabungan pada Bursa Efek Indonesia Periode 2002-2011. Jurnal Ilmiah Mahasiswa Universitas Surabaya, 2(1). 